\title{
Retention patterns of asbestos fibres in lung tissue among asbestos cement workers
}

\author{
M Albin, F D Pooley, U Strömberg, R Attewell, R Mitha, L Johansson, H Welinder
}

\begin{abstract}
Retention patterns in lung tissue (determined by transmission electron microscopy and energy dispersive spectrometry) of chrysotile, tremolite, and crocidolite fibres were analysed in 69 dead asbestos cement workers and 96 referents. There was an accumulation of tremolite with time of employment. Among workers who died within three years of the end of exposure, the 13 with high tremolite concentrations had a significantly longer duration of exposure than seven in a low to intermediate category (medians $32 v 20$ years; $p=0.018$, one sided). Crocidolite showed similar patterns of accumulation. In workers who died more than three years after the end of exposure, there were no correla-
\end{abstract} tions between concentrations of amphibole fibres and time between the end of exposure and death. Chrysotile concentrations among workers who died shortly after the end of exposure were higher than among the referents (median difference in concentrations 13 million fibres (f)/g dry weight; $p=0.033$, one sided). No quantitative differences in exposure (duration or intensity) could be shown between workers with high and low to intermediate concentrations. Interestingly, all seven workers who had had a high intensity at the end of exposure $(>2.5 \mathrm{f} / \mathrm{ml})$, had low to intermediate chrysotile concentrations at death, whereas those with low exposure were evenly distributed ( 31 subjects in both concentration categories); hence, there was a dependence between last intensity of exposure and chrysotile concentration $(p=0.014)$. Among 14 workers with a high average intensity of exposure, both those $(n=5)$ with high tissue concentrations of chrysotile and those $(n=10)$ with high tissue concentrations of tremolite fibres had more pronounced fibrosis than those with low to intermediate concentrations (median fibrosis grades for chrysotile: $2 v 1, p=0.021$; for tremolite: $2 v 0 \cdot 5, \mathrm{p}=0 \cdot 012$ ). Additionally, workers who died shortly after the end of exposure with high concentrations of chrysotile and crocidolite had smoked more than those with low to intermediate concentrations (medians for chrysotile 35 $v 15$ pack-years, $p=0.030$; for crocidolite $37 v 15$ pack-years, $p=0.012$ ). The present data indicate that chrysotile has a relatively rapid turnover in human lungs, whereas the amphiboles, tremolite and crocidolite, have a slower turnover. Further, chrysotile retention may be dependent on dose rate. Chrysotile and crocidolite deposition and retention may be increased by tobacco smoking; chrysotile and tremolite by fibrosis.

(Occup Environ Med 1994;51:205-211)

The persistence of mineral fibres in lung tissue is believed to be one of the major determinants for their ability to induce fibrosis and malignancies, ${ }^{1}$ and is thus crucial for evaluation of risk and preventive measures. This point has, however, been contested by other authors, claiming that the fibres that pass through the tissue might well be the causal agent. $^{2}$

Animal data on retention of particular asbestos types have been reported in several studies, ${ }^{3-6}$ indicating a faster elimination of chrysotile than amphibole fibres, possibly due to fragmentation of chrysotile (into shorter and thinner fibres) as opposed to simultaneously administered amosite. ${ }^{7}$ Apart from fibre type, retention is determined by size, with a faster elimination for short fibres than for long ones. ${ }^{8-10}$ Accordingly, Davis reported that the clearance after six months in rats was $14 \%$ for long and $20 \%$ for short fibre amosite, compared with $55 \%$ for long and $90 \%$ for short chrysotile. ${ }^{11}$

Human data are scarce. Analyses of mineral fibre concentrations in chrysotile miners and millers do, however, indicate a much higher retention of tremolite than of chrysotile asbestos. ${ }^{1213}$ Only three studies, providing rough quantitative estimates of the clearance rates among humans, have been published. The data were based on miners and millers (chrysotile and tremolite), ${ }^{14}$ crocidolite miners, ${ }^{15}$ and on mesothelioma series (amosite and crocidolite). ${ }^{16}$ Half times of some years to decades were reported. It is obvious, however, that the uncertainty of these estimates was considerable. Thus, more studies of accumulation and elimination patterns are needed.

We have studied retention patterns of asbestos fibres among asbestos cement workers.

\section{Material and methods}

MATERIAL

The material consisted of lung tissue specimens preserved at the Lund University Hospital at necropsy examination of 75 
asbestos cement workers and 96 controls. The workers were those (except one who was excluded as he was found to have been a contract worker) employed by an asbestos cement factory. ${ }^{17-19}$ Only the 69 workers with information on exposure were included in the analysis. The controls were drawn from the same hospital files, including all causes of death, and chosen to match the workers for sex, age, and calendar year at death. Age (asbestos cement workers: median 68 years, referents: median 67 years), sex (five women in each group), and calendar year of death (medians 1972 in both groups) were similar among the asbestos cement workers finally included and the referents.

\section{EXPOSURE}

Chrysotile was the major asbestos exposure. Tremolite is, however, known to be a common contaminant in commercial chrysotile qualities. $^{20}$ Some amosite was used up to 1956, crocidolite until 1966; both were used intermittently. Dust measurements were made from 1956 onwards; they reflect the concentrations of all fibres, without information on the different components. Some filters from dust sampling during the late 1960 s are available. Preliminary data from determination of fibre type in airborne dust, with an analytical transmission electron microscope, have shown chrysotile and singular tremolite fibres (S Krantz, personal communication). A more detailed description of available occupational hygiene data has been published in a previous paper. ${ }^{17}$

The data on dust concentrations, production, and dust control were used by an experienced industrial hygienist ( $\mathrm{HW}$ ) to calculate task specific exposure estimates (average intensities; $\mathrm{f} / \mathrm{ml}$ air) during five year periods. These were combined with the work histories to obtain individual estimates of cumulative dose (f-years $/ \mathrm{ml}$ ), average intensity of exposure throughout employment, and last observed intensity.

Only workers performing milling, mixing, sawing, and polishing operations, or sweeping of the asbestos barn, were estimated to have average intensities of exposure $>2$ fibres $/ \mathrm{ml}$.

Individual exposure estimates could not be calculated for six workers, due to missing work histories. Among the remaining 69 workers, mean duration of employment was 18 (median 15) years, and mean time between the end of exposure and death 12 years (median 10). The mean estimated average intensity of exposure was 1.7 (median $1 \cdot 2$, range $0 \cdot 0-7 \cdot 3) \mathrm{f} / \mathrm{ml}$, and the mean last intensity of exposure 1.2 (median $1 \cdot 0$, range $0 \cdot 0-6 \cdot 1) \mathrm{f} / \mathrm{ml}$

Data on smoking habits were obtained for all but three workers $(n=66)$ by a postal inquiry sent to the next of kin. The accumulated lifetime tobacco consumption was calculated as pack-years.

TISSUE ANALYSES

Dust extracts were prepared in a standard manner. The analyses were performed with a
Philips 400T transmission electron microscope fitted with an Edax $x$ ray analysis system at a magnification of 20000 . Fibrous particles were identified, sized, and counted without restrictions as to minimum length. Mineral fibre concentrations were recorded as $\mathrm{f} / \mathrm{g}$ of dried tissue. ${ }^{1921}$

A histopathological grading of fibrosis was made, as described earlier. ${ }^{18}$

\section{STATISTICS}

Tabulation of chrysotile concentrations among the referents for different strata of tissue weights showed an inverse relation between tissue weight and chrysotile concentration (table 1). This finding was not confounded by age or cumulative exposure. A standardisation curve was obtained through linear interpolation (linear extrapolation for small weights and constant extrapolation for large ones) between the points (median weight, median concentration) in each class. No relation was found between sample weight and concentration of the amphibole fibres.

Chrysotile fibre concentrations among the exposed workers, measured both as observed and as residual concentrations from the standardisation curve, were dichotomised at the 60th percentile (residual concentration $22 \times 10^{6} \mathrm{f} / \mathrm{g}$ dry weight) into one group with low to intermediate and one with a high concentration. Similarly, the amphibole concentrations were dichotomised (tremolite: 60th percentile $=0.3$ million, crocidolite: 60 th percentile $=4$ million $\mathrm{f} / \mathrm{g}$ ). The 60 th percentile was chosen to provide a sufficient number of observations, but still strictly positive observations in the high concentration category. There was no need for adjustment of observed concentrations of the amphibole fibres.

The 69 workers with individual exposure estimates were included in the analysis of retention patterns. A maximum of three years between end of exposure and death was assumed to exclude substantial elimination. Associations, among those who died within three years of end of employment, were investigated between possible determinants (age at start of employment, age at death, year of employment, duration of exposure, average intensity of exposure throughout employment, intensity at the end of exposure, time between the end of exposure and death, tobacco consumption, and grade of fibrosis) and fibre concentration. These results were used to postulate to which concentration category the others, who died more than three years after the end of employment,

Table 1 Chrysotile concentrations (medians) for different strata of dry weights of lung tissue among 96 referents (192 tissue samples)

\begin{tabular}{lclll}
\hline & & \multicolumn{2}{l}{$\begin{array}{l}\text { Chrysotile } \\
\text { concentration }\end{array}$} \\
\cline { 5 - 5 } Dry weight $(w(m g))$ & Median & & $\begin{array}{l}\text { flgdry } \\
\left.\text { weight } \times 10^{\circ}\right)\end{array}$ & No \\
\hline Interval & 8 & 44 & 26 \\
\hline $0<\mathrm{w} \leqslant 10$ & 15 & 31 & 70 \\
$10<\mathrm{w} \leqslant 20$ & 25 & 24 & 17 \\
$20<\mathrm{w} \leqslant 30$ & 35 & 21 & 39 \\
$30<\mathrm{w} \leqslant 40$ & 35 & 12 & \\
$\mathrm{w}>40$ & 58 & &
\end{tabular}




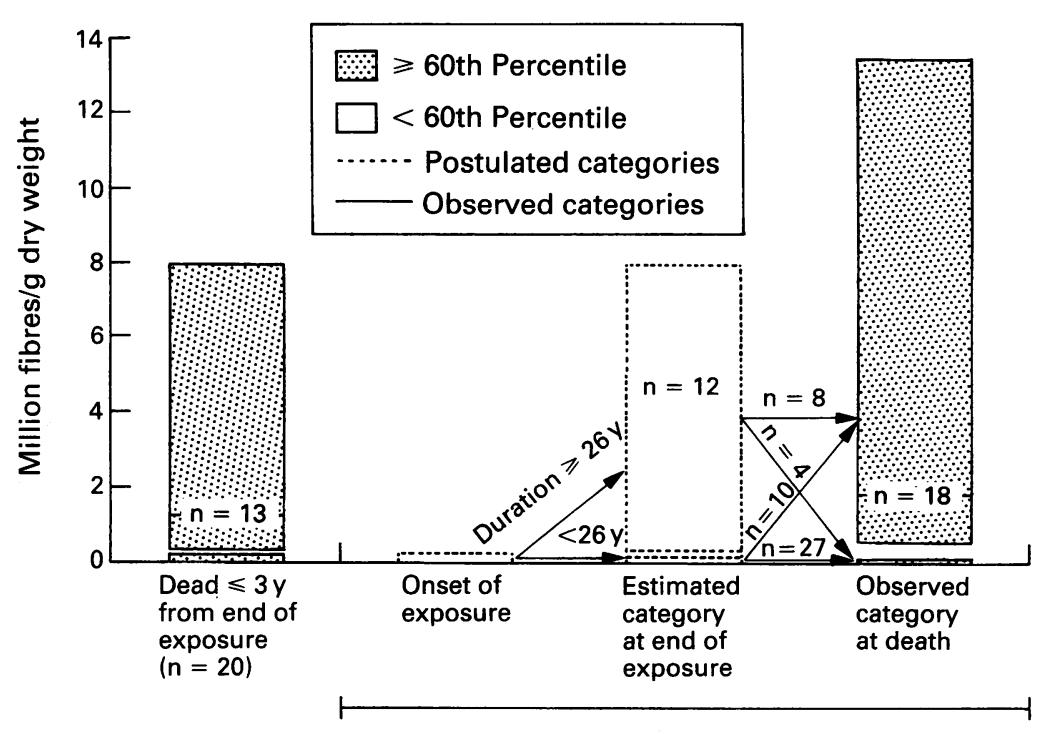

Dead $>3$ y from end of exposure $(n=49)$

Figure 1 Model for the accumulation and elimination of tremolite fibres in lung tissue from 69 asbestos cement workers (medians are indicated within observed categories).

belonged when exposure ended. Subsequently, relations between the inferred elimination patterns (from the postulated category at end of exposure to the observed category at death) and the determinants mentioned, were investigated among these workers (figs 1 and 2). Differences in the determinants were compared by the Mann-Whitney test. One sided tests were used for associations in which the alternative hypothesis was supported by data from other studies; however, the $p$ values are two sided unless otherwise stated. Also, the given confidence intervals (CIs) are based on the Mann-Whitney test.

One of the reasons for analysing accumulation and elimination patterns is the fact that the data are not satisfactorily described by the following classic accumulation and elimination model:

Fibre tissue concentration $=\mathrm{A}$ (average intensity) [1-exp $\left.\left(-B t_{1}\right)\right] \exp \left(-B t_{2}\right)$, where $t_{1}$ is duration of exposure, $t_{2}$ is the time between end of exposure and death, and $A$ and $B$ are the variables to be estimated. The model variable A multiplied by average intensity of exposure corresponds to the steady state concentration under constant exposure, and the variable $B$ is an elimination constant, related to clearance half life $\left(T_{1 / 2}=\ln 2 / B\right)$.

The influences of last and average intensity of exposure, on tissue concentrations (dichotomised at the 60 th percentile) of chrysotile and tremolite at death were analysed by dichotomising the intensities at $2.5 \mathrm{f} / \mathrm{ml}$ into low and high intensity groups. This limit was chosen to provide a sufficient number of observations in each group. The independence between intensity of exposure and tissue concentration was examined by Fisher's exact test (two sided). Differences in the determinants were first examined between the intensity groups, and then for the concentration categories within each intensity group.

Possible confounding of observed associations between tobacco consumption and mineral fibre concentrations by age at death, duration, and year of employment was examined by first dividing the data into two strata (with the common stratum bound close to

Table 2 Associations between average intensity of exposure throughout employment, intensity at end of exposure, and concentration category of chrysotile or tremolite fibres in lung tissue among 69 asbestos cement workers. Covariates not in table were not significant in any test

\begin{tabular}{|c|c|c|c|c|c|c|}
\hline & \multicolumn{3}{|c|}{ Chrysotile* $^{*}$} & \multicolumn{3}{|c|}{ Tremolite } \\
\hline & \multicolumn{2}{|c|}{ Fibre concentration } & \multirow[b]{2}{*}{ p Value } & \multicolumn{2}{|c|}{ Fibre concentration } & \multirow[b]{2}{*}{ p Value } \\
\hline & High & $\begin{array}{l}\text { Low to } \\
\text { intermediate }\end{array}$ & & High & $\begin{array}{l}\text { Low to } \\
\text { intermediate }\end{array}$ & \\
\hline \multicolumn{7}{|c|}{ Average intensity } \\
\hline $\begin{array}{l}>2 \cdot 5 \text { (median } 4 \cdot 3(\text { range } 2 \cdot 7-7 \cdot 3) \text { ) } \mathrm{f} / \mathrm{ml} \text { air: } \\
\text { Subjects }(\mathrm{n}) \\
\text { Average intensity }(\mathrm{f} / \mathrm{ml}) \\
\text { Fibrosis grade } \\
\text { Exposure time (y) } \\
\text { Time to death (y) }\end{array}$ & $\begin{array}{c}5 \\
3 \cdot 2 \\
2 \cdot 0 \\
17 \\
3 \cdot 7\end{array}$ & $\begin{array}{l}9 \\
5 \cdot 0 \\
1 \cdot 0 \\
21 \\
10\end{array}$ & $\begin{array}{l}0.028 \dagger \\
0.021 \dagger \\
0.64 \dagger \\
0.38 \dagger\end{array}$ & $\begin{array}{c}10 \\
3 \cdot 8 \\
2 \cdot 0 \\
25 \\
6 \cdot 7\end{array}$ & $\begin{array}{l}4 \\
5 \cdot 0 \\
0 \cdot 5 \\
9 \cdot 7 \\
9 \cdot 2\end{array}$ & $\begin{array}{l}0.32 \dagger \\
0.012 \dagger \\
0.066 \dagger \\
0.48 t\end{array}$ \\
\hline $\begin{array}{l}\leqslant 2.5(\text { median } 1.0(\text { range } 0.0-2 \cdot 3)) \mathrm{f} / \mathrm{ml} \text { air: } \\
\text { Subjects }(\mathrm{n}) \\
\text { Average intensity }(\mathrm{f} / \mathrm{ml}) \\
\text { Fibrosis grade } \\
\text { Exposure time }(\mathrm{y}) \\
\text { Time to death }(\mathrm{y})\end{array}$ & $\begin{array}{c}26 \\
0 \cdot 9 \\
1 \cdot 0 \\
16 \\
9 \cdot 8\end{array}$ & $\begin{array}{l}29 \\
1 \cdot 2 \\
1 \cdot 0 \\
12 \\
13\end{array}$ & $\begin{array}{l}0.55 \ddagger \\
0.039 \dagger \\
0.29 \dagger \\
0.27 \dagger \\
0.62 \dagger\end{array}$ & $\begin{array}{r}20 \\
1 \cdot 0 \\
1 \cdot 5 \\
30 \\
8 \cdot 6\end{array}$ & $\begin{array}{l}35 \\
1 \cdot 0 \\
1 \cdot 0 \\
10 \\
13\end{array}$ & $\begin{array}{l}0.032 \ddagger \\
0.94 \dagger \\
0.20 \dagger \\
0.0015 \dagger \\
0.14 \dagger\end{array}$ \\
\hline \multicolumn{7}{|l|}{$>2.5($ median $4.6($ mange $2.7-6.1)) \mathrm{f} / \mathrm{ml}$ air. } \\
\hline $\begin{array}{l}\text { Subjects (n) } \\
\text { Average intensity }(\mathrm{f} / \mathrm{ml}) \\
\text { Fibrosis grade } \\
\text { Exposure time (y) } \\
\text { Time to death (y) }\end{array}$ & $\begin{array}{l}0 \\
\overline{-} \\
-\end{array}$ & $\begin{array}{r}7 \\
5 \cdot 0 \\
1 \cdot 0 \\
21 \\
9 \cdot 7\end{array}$ & $\begin{array}{l}\bar{z} \\
\bar{z}\end{array}$ & $\begin{array}{l}4 \\
5 \cdot 0 \\
1 \cdot 5 \\
15 \\
10\end{array}$ & $\begin{array}{l}3 \\
5 \cdot 0 \\
0 \\
12 \\
4\end{array}$ & $\begin{array}{l}0.48 t \\
0.064 t \\
0.29 t \\
0.72 t\end{array}$ \\
\hline $\begin{array}{l}\leqslant 2.5(\text { median } 0.9(\text { range } 0.0-2.3)) \mathrm{f} / \mathrm{ml} \text { air: } \\
\text { Subjects }(\mathrm{n}) \\
\text { Average intensity }(\mathrm{f} / \mathrm{ml}) \\
\text { Fibrosis grade } \\
\text { Exposure time }(\mathrm{y}) \\
\text { Time to death }(\mathrm{y}) \subseteq\end{array}$ & $\begin{array}{c}31 \\
1 \cdot 0 \\
1 \cdot 0 \\
17 \\
9 \cdot 6\end{array}$ & $\begin{array}{l}31 \\
1 \cdot 20 \\
1 \cdot 0 \\
12 \\
10\end{array}$ & $\begin{array}{l}0.014 \ddagger \\
0.28 \dagger \\
0.78 \dagger \\
0.22 \dagger \\
0.40 \dagger\end{array}$ & $\begin{array}{c}26 \\
1 \cdot 2 \\
2 \cdot 0 \\
31 \\
9\end{array}$ & $\begin{array}{l}36 \\
1.0 \\
1.0 \\
10 \\
13\end{array}$ & $\begin{array}{l}0.46 \ddagger \\
0.15 t \\
0.057 \dagger \\
0.0003 \dagger \\
0.027 \dagger\end{array}$ \\
\hline
\end{tabular}

All Data values are medians; categories are high chrysotile median 61 (range 22 to 430), low to intermediate median 0.5 (range -14 to 22), high tremolite median 1.5 (range 0.3 to 13), low to intermediate median 0.0 (range $0 \cdot 0$ to $0 \cdot 2$ ) $\mathrm{f} / \mathrm{g} \times 10^{6}$. ^ Residual chrysotile concentrations as computed from a standardisation curve (see text).

†Mann-Whitney test for differences between the concentration categories.

fFisher's exact test for independence between intensity and concentration categories (all 69 workers).

fTime between cessation of exposure and death.

The betwen cessuidn of exposure and death. 
the median of the potential confounder), and then calculating stratum specific median differences for the determinant between the categories (and corresponding $\mathrm{p}$ values), as well as a pooled $p$ value. ${ }^{22}$ The observed influence of grade of fibrosis on mineral fibre concentrations by age and tobacco consumption was examined for possible confounding in the same way.

Underlying cause of death, as coded by the National Swedish Bureau of Statistics, was grouped into possibly asbestos related deaths (four groups: mesothelioma, lung cancer, fibrosis, colorectal cancer) and other causes. Differences in the fibre concentrations between the other causes and each asbestos related group of deaths were assessed with the Mann-Whitney test.

\section{Results}

CHRYSOTILE

The 20 workers who had died within three years of the end of employment had higher chrysotile concentrations than the referents ( $n=96$; median difference in concentrations 13 million $\mathrm{f} / \mathrm{g}, \mathrm{p}=0.033$, one sided).

No differences in average, or last intensity, or duration of exposure were found between the nine workers with high and the 11 workers with low to intermediate chrysotile concentrations. The only determinant factor that differed significantly between the two groups was tobacco consumption. Workers with high chrysotile concentrations had a two fold higher median tobacco consumption than workers with low to intermediate concentrations (35 $v 15$ pack-years, $\mathrm{p}=0.030$ ). Stratification suggested, however, that this relation might be confounded by duration (and year) of employment.

Two different classifications were made of all workers with individual exposure estimates $(n=69)$. They were categorised as either having a high $(>2.5 \mathrm{f} / \mathrm{ml})$ or low $(\leqslant 2.5 \mathrm{f} / \mathrm{ml})$ last and average intensity of exposure (table 2). There were no significant differences in the other determinants between these high and low intensity groups.

The association between last intensity and category of tissue concentration was significant $(p=0.014)$; all workers with a high last intensity of exposure had low to intermediate chrysotile concentrations in lung tissue. No such relation was observed for average intensity. Within the group with a high average intensity of exposure, grade of fibrosis was higher among those with high chrysotile concentrations than among those with low to intermediate concentrations $(p=0.021)$. Stratification did not indicate that this finding was confounded by age or tobacco consumption.

The results of the observed, unstandardised, chrysotile concentrations were similar to those obtained with the standardised concentrations.

\section{TREMOLITE}

Analysis of tremolite concentrations in the workers $(n=20)$ who had died within three years of the end of exposure showed that duration of exposure differed significantly, with a median of 32 years for workers in the high category $(n=13)$, and 20 years in the low to intermediate category $(p=0.018$, one sided; fig 1). In the low to intermediate category $(n=7)$, the upper limit of the $95 \% \mathrm{CI}$ for duration of exposure was 26 years. That limit was used to postulate the concentration category at the end of exposure for those living $>3$ years after the end of exposure.

Tobacco consumption in the 20 workers did not differ between the two tissue concentration categories $(p=0 \cdot 24)$.

Among workers living $>3$ years after end of exposure, those employed for 26 years or more were postulated to have belonged to the high category at the end of exposure, and those with shorter durations as belonging to the low to intermediate category. The time that elapsed between the end of exposure and death among those postulated to have belonged to the high concentration category at the end of exposure, was not significantly associated with observed concentration category of tremolite fibres at death (fig 1; high $(n=8)$, median 13 years, low to intermediate $(\mathrm{n}=4)$ median 10 years, $\mathrm{p}=0.67$ ).

Among workers postulated to have belonged to the high category at end of exposure, those observed to be in the high concentration category at death, had significantly higher grades of fibrosis (medians $2.0 v 0.5$; $\mathrm{p}=0.014$ ), than those in the low to intermediate category at death (with no indications of confounding by age or tobacco consumption). They also had slightly, but significantly, higher average intensities of exposure (medians $1.0 v 0.6 \mathrm{f} / \mathrm{ml} ; \mathrm{p}=0.011$ ) than the others. This may indicate that intensity affects tissue concentrations of tremolite, although this could not be shown in the analysis of accumulation.

The 10 workers postulated to have belonged to the low to intermediate concentration category at the end of exposure, but found to be in the high concentration category at death, tended to have a higher cumulative exposure $(p=0.055)$ than those 27 workers both postulated and found to be in the low to intermediate category.

Classification of all workers into high $(>2.5 \mathrm{f} / \mathrm{ml})$ and low groups of last and average intensity of exposure (table 2), did not show any differences in the other determinants between the groups, except that workers with a high average intensity were older at the end of exposure than those with a low average intensity $(p=0.028)$.

Distributions of high and low to intermediate tremolite concentrations were compared for the intensity groups. There was a significant association between average intensity and tremolite concentration $(p=0.032)$ but no such relation was seen for last intensity. Among workers with a low last intensity of exposure, those with high tremolite concentrations in lung tissue had a longer duration of exposure than those with low concentrations $(p=0.0003)$. Also, workers 


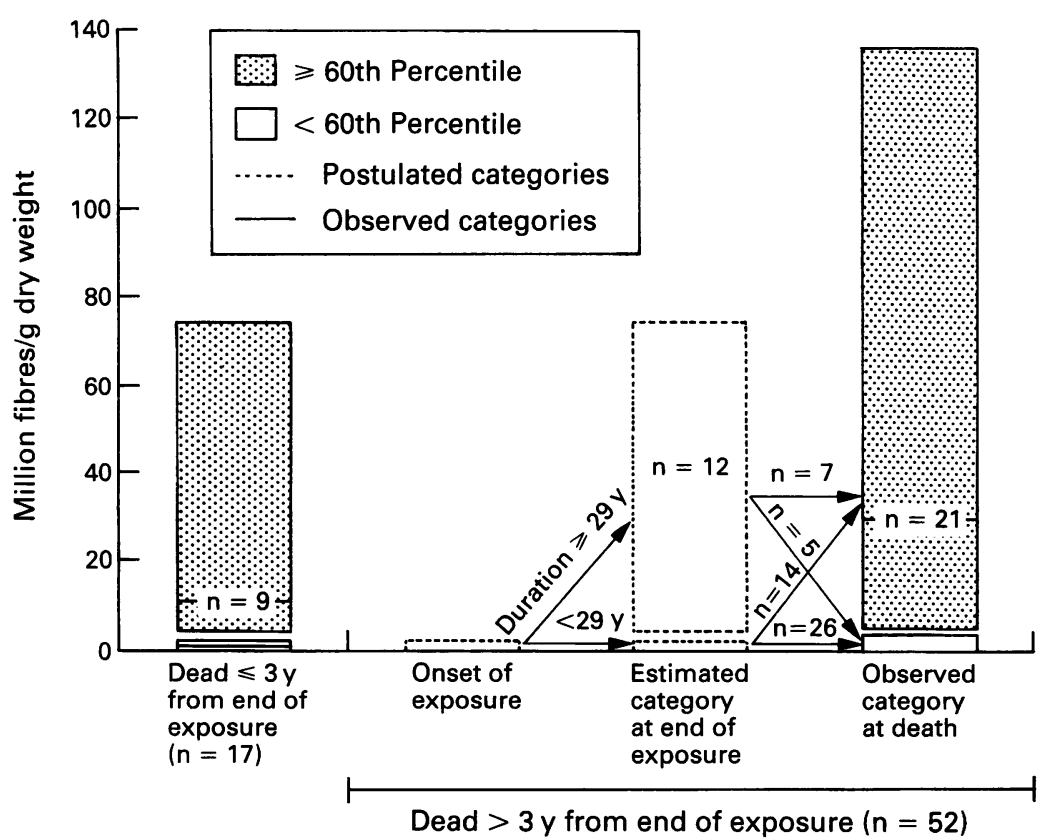

Figure 2 Model for the accumulation and elimination of crocidolite fibres in lung tissue from 69 asbestos cement workers (medians are indicated within observed categories).

with low concentrations had a longer time between the end of exposure and death than those with high concentrations $(p=0.027)$.

Among workers with a high average intensity of exposure, those with high tissue concentrations had a higher grade of fibrosis $(p=0.012)$. Stratification indicated that age was not a confounding factor in this context, whereas tobacco consumption might be. Among workers with a low average intensity, those with high concentrations had a longer duration of exposure $(p=0.0003)$.

\section{CROCIDOLITE}

Crocidolite use at the plant ended in 1966. Thus that year was regarded as the end of exposure in the analyses of relations between category of tissue concentration of crocidolite and possible determinants. In the 17 persons who died within three years of end of exposure, longer durations of exposure were seen for those in the high concentration category $\cdot(n=9$, median 32 years $)$ compared with those in the low to intermediate $(n=8$, median $25,95 \%$ CI one sided upper limit

Table 3 Mineral fibre concentrations ( $f / g$ dry weight $\left.\times 10^{6}\right)$ in lung tissue from 75 asbestos cement workers by cause of death

\begin{tabular}{|c|c|c|c|c|c|}
\hline & \multicolumn{3}{|l|}{ Tumour } & \multirow[b]{2}{*}{$\begin{array}{l}\text { Fibrosis } \\
(n=2)\end{array}$} & \multirow[b]{2}{*}{$\begin{array}{l}\text { Other } \\
(n=60)\end{array}$} \\
\hline & $\begin{array}{l}\text { Mesothelioma } \\
(n=7)\end{array}$ & $\begin{array}{l}\text { Lung } \\
(n=2)\end{array}$ & $\begin{array}{l}\text { Colorectal } \\
(n=4)\end{array}$ & & \\
\hline $\begin{array}{l}\text { Chrysotile: } \\
\text { Observed } \\
\text { Residual } \neq\end{array}$ & $\begin{array}{l}62 \dagger \\
14\end{array}$ & $\begin{array}{l}16,38 \\
5 \cdot 1,9 \cdot 6\end{array}$ & $\begin{array}{l}35 \\
13\end{array}$ & $\begin{array}{l}37,86 \\
17,64\end{array}$ & $\begin{array}{l}43 \\
15\end{array}$ \\
\hline $\begin{array}{l}\text { Amphiboles } \\
\text { Crocidolite } \\
\text { Amosite } \\
\text { Tremolite } \\
\text { Anthophyllite }\end{array}$ & $\begin{array}{c}62^{\star \star} \\
54^{\star \star} \\
6 \cdot 8 \\
2 \cdot 9^{\star \star} \\
1 \cdot 7^{\star}\end{array}$ & $\begin{array}{l}16,22 \\
1 \cdot 9,14 \\
4 \cdot 9,6 \cdot 2^{\star} \\
1 \cdot 2,4 \cdot 6^{\star} \\
0 \cdot 85,4^{\star} \cdot 6^{\star}\end{array}$ & $\begin{array}{l}5 \cdot 0 \\
3 \cdot 8 \\
0 \cdot 52 \\
0 \cdot 25 \\
0 \cdot 38\end{array}$ & $\begin{array}{l}44,90^{\star} \\
39,69^{\star} \\
1 \cdot 0,17 \\
2 \cdot 2,2 \cdot 3^{\star} \\
0 \cdot 95,1 \cdot 0\end{array}$ & $\begin{array}{l}4 \cdot 2 \\
1 \cdot 6 \\
0 \cdot 18 \\
0 \\
0\end{array}$ \\
\hline Total fibres $\$$ & $211^{\star}$ & 46,141 & 43 & 132,168 & 66 \\
\hline
\end{tabular}

${ }^{\star} \mathrm{p}<0.05 ;{ }^{\star \star} \mathrm{p}<0.01 v$ deaths from other diseases (two sided, Mann-Whitney test). $t$ Given as medians for more than two observations.

$\ddagger$ Residual chrysotile concentrations as computed from a standardisation curve (see text). fIncluding non-asbestos fibres.
$=29$ years, $p=0.027$; fig 2). Also, year of onset of exposure differed $(p=0.0048)$ between the two tissue concentration categories. All those in the high category had started employment in the 1920 s or 1930 s, compared with four out of eight in the low to intermediate category.

Workers in the high category also had a higher tobacco consumption than those in the low category (medians $37 v 15$ pack-years, $\mathrm{p}=0.013$ ); stratification did not indicate confounding by age, or duration of employment.

Among workers who died more than three years after the end of exposure, those employed for 29 years or more were postulated to have belonged to the high category at the end of exposure, and those with shorter durations of employment as belonging to the low to intermediate category. Time between the end of exposure and death was similar among workers assumed to have decreased their tissue concentrations (from postulated high to observed low to intermediate, $n=5$ ), and workers believed to have been constantly in the high category $(n=7$, medians 5.6 and 5.5 years, $p=0.87$ ). Workers in the constantly high category had a higher average intensity of exposure than those who had changed category (medians $2.7 v 0.8$, $\mathrm{p}=0.028$ ).

Among workers assumed to have belonged to the low to intermediate category at the end of exposure, those actually found in the high concentration category at death $(n=14)$, had significantly longer durations of employment than those observed in the low to intermediate category $(n=26$; medians $11 v 3.8$ years, $p=0.0062$ ).

\section{AMOSITE}

No analyses of relations between amosite concentrations and possible determinants were performed as only four workers had died within three years from the end of exposure (with 1956 as the end point for possible exposure at the plant).

FIBRE CONCENTRATIONS AND CAUSE OF DEATH Classification of the asbestos cement workers by cause of death gave small numbers for each asbestos related cause of death (pleural mesothelioma seven; lung cancer two; lung fibrosis two). Colorectal cancer $(n=4)$ was also examined as a separate category, as a relation between exposure and mortality from this cancer was previously found in the cohort. ${ }^{17}$ Amphibole concentrations in workers who died of mesothelioma, lung cancer, or lung fibrosis, were generally higher than among workers who died from other causes (table 3). No such pattern was found for chrysotile. Fibre concentrations in workers who died from colorectal cancer were similar to those among workers who died from other diseases.

\section{Discussion}

Any relation between intensity of exposure 
and fibre concentrations in lung tissue are likely to be obscured by several factors. Misclassification of exposure is a problem for the early period, as no dust measurements were performed before 1956. Even thereafter, difficulties remain, due to the use of different methods, and changes in the strategy for monitoring of dust concentrations. Further, the information on different work tasks performed by each worker is incomplete, and so is our information on the use of respirators (note that workers exposed to high concentrations of airborne dust are more likely to have worn respirators). The two exposure variables used-intensity and duration-are intercorrelated, as exposure intensities declined with calendar year of exposure. Thus, workers with long durations generally also have higher estimated average intensities of exposure. This hampers the possibility of evaluating the exposure variables separately, and might partly also explain why cumulative dose did not contribute more information than average intensity and duration analysed separately.

Further, fibre type was not characterised in the sampled dust. Use of crocidolite and amosite was intermittent at the plant, and is poorly defined for each worker, both in terms of duration and intensity. The finding of a strong association between high concentrations of crocidolite and start of employment in the 1920s and 1930s is useful as it indicates that exposure during these decades might be considered as an additional determinant of risk in further studies of relations between exposure and response.

Our material permitted only analyses with crude methods to evaluate accumulation and elimination, without quantitative estimates of clearance rates. The fact that those workers observed in the high, but postulated to be in the low to intermediate, concentration categories of crocidolite and tremolite fibres, tended to have a higher exposure than the others, indicates misclassification due to the strict criteria for postulating that a worker belonged to the high concentration category at the end of exposure. Application of a more complicated model to the data yielded highly unstable estimates (results not presented).

Further, we could not account for the sample site in the lung, as this was usually unspecified. Estimates of the importance of sample site vary between a factor of two and eight (generally, the highest concentrations are found in the peripheral lower lobe ${ }^{23-25}$; and FD Pooley, unpublished data). Clearly, the possible sources of errors already mentioned imply that our results should be interpreted with some caution.

We found a negative relation between sample weight and chrysotile concentration. Part of the explanation might be that the dust from a heavy sample will be more dense and thus there will be an increased probability of a covering effect. This would be most likely to affect thin and short fibres, such as chrysotile.

No relations indicating a continuous increase in chrysotile concentrations in lung tissue with increasing duration and intensity of exposure were found for workers who died within three years of the end of exposure. The chrysotile fibres recovered from the lungs of these workers have a geometric mean length of only $1 \cdot 1 \mu \mathrm{m}$, which is less than half of the mean chrysotile length found among textile workers, and mean lengths for amphibole fibres in both groups. ${ }^{26}$ Thus, as short fibre size is a determinant for a rapid clearance, a comparatively short retention of chrysotile would be expected in this study from the size data only. The lack of relations between tissue concentration and duration or average intensity of exposure is also compatible with the observation that workers with a high last intensity seemed to have a faster clearance than those with a low intensity. These findings are in accordance with a previous report indicating an adaptive clearance of chrysotile, possibly due to an enhancement of macrophage activity through the cytotoxicity of chrysotile. ${ }^{14}$

Workers with a high average intensity of exposure and high chrysotile or tremolite counts in lung tissue had more pronounced fibrosis than those with low to intermediate concentrations. This might indicate an impaired clearance due to the fibrosis as the exposure was not significantly higher in the high concentration category, as analysed by a crude stratification. An impaired clearance in fibrotic lungs has previously been suggested by Timbrell. ${ }^{27}$

Indications of accumulation in lung tissue with duration of exposure were seen for tremolite and crocidolite. No clear patterns indicating elimination after the end of exposure were found. This is in accordance with former findings, mainly from animal studies, ${ }^{3-7}$ and among workers from chrysotile textile and mining industries, ${ }^{28}$ that elimination is slow for amphibole asbestos.

Interestingly, there were indications of an association between tobacco consumption and high category of tissue concentrations of chrysotile and crocidolite (but not tremolite). Stratification on the other time dependent determinants, however, indicated that the association found for chrysotile, might be confounded by duration (and year) of employment. Thus the association we found between tobacco consumption and chrysotile concentrations should be interpreted with some care.

A causal association is, however, supported by previous findings. In a series of cases of lung cancer, high tobacco consumption was associated with high total particle counts in lung tissue. ${ }^{29}$ Further, an increased accumulation of amosite fibres has been found in the bronchial walls of experimental animals exposed to cigarette smoke. ${ }^{30} \mathrm{~A}$ positive association between tobacco consumption and accumulation of asbestos fibres might partly explain why smokers are more likely than non-smokers to develop fibrosis ${ }^{31}$ and lung cancer ${ }^{32}$ when exposed.

Comparisons of fibre concentrations and cause of death displayed generally higher 
amphibole concentrations for asbestos related diagnoses than other diseases, whereas the comparisons were similar for chrysotile concentrations. The results should be interpreted with care due to the small numbers in each group of asbestos related diagnoses. They are, however, in agreement with previous findings made among east London factory workers. ${ }^{33}$

This study shows different kinetics for amphibole and chrysotile fibres in human lung tissue. Amphibole fibre concentrations increase with duration of exposure, whereas chrysotile concentrations do not. Furthermore, it supports a former finding of a possible adaptive clearance of chrysotile. Also, we found indications of an impaired clearance among workers with fibrosis and workers with a high tobacco consumption. The association between increased amphibole concentrations in lung tissue and death from asbestos related causes suggests that workers who died from these causes had a higher amphibole exposure or a poorer clearance of these fibres than the others. The findings thus support the hypothesis that adverse effects are associated rather with the fibres retained (amphiboles), than with the ones being cleared (largely chrysotile).

This study was supported by grants from the Swedish Work Environment Fund and from the Medical Faculty, Lund University. Lars Rylander, MSc, made the graphs. This is gratefully acknowledged.

1 Wagner JC. Mesothelioma and mineral fibers. Cancer 1986;57:1905-11.

2 Doll R, Peto J. Asbestos. Effects on health of exposure to asbestos. $A$ report to the Health and Safety Commission. London: HMSO 1985.

3 Wagner JC, Skidmore JW. Asbestos dust deposition and retention in rats. Ann N Y Acad Sci 1965;132:77-86.

4 Wagner JC, Berry G, Skidmore JW, Timbrell V. The effects of inhalation of asbestos in rats. $\mathrm{Br} \mathcal{F}$ Cancer 1974;29:252-69.

5 Middleton AP, Beckett ST, Davis JMG. A study of the short-term retention and clearance of inhaled asbestos using UICC standard reference samples. In: Walton WH, ed. Inhaled particles IV. Oxford: Pergamon Press, 1977:247-57.

6 Wagner JC, Griffiths DM, Munday DE. Recent investigations in animals and humans. In: Wagner JC, ed. Biological effects of chrysotile (Accomplishments in Oncology. Vol 1. No 2). Philadelphia: Lippincott, 1986 111-20.

7 Churg A, Wright JL, Gilks B, Depaoli L. Rapid shortterm clearance of chrysotile compared with amosite asbestos in the guinea pig. Am Rev Respir Dis 1989;139. 885-90.

8 Morgan A. Effect of length on the clearance of fibres from the lung and on body formation. In: Wagner JC, ed Biological effects of mineral fibres. Lyon: IARC, 1980:vol 1, 329-35. (IARC Sci Publ No 30).

9 Pooley FD, Clark NJ. A comparison of fibre dimensions in chrysotile, crocidolite and amosite particles from samples of airborne dust and from post-mortem lung tissue specimens. In: Wagner JC, ed. Biological effects of tissue specimens. In: Wagner JC, ed. Biological effects of
mineral fibres. Lyon: IARC, 1980: vol 1, 79-86. (IARC mineral fibres. Lyo

10 Davis JMG, Jones AD. Comparisons of the pathogenicity of long and short fibres of chrysolite asbestos in rats. $B$ f Exp Pathol 1988;69:717-37.
11 Davis JMG. Mineral fibre carcinogenesis: experimental data relating to the importance of fibre type, size, deposition, dissolution and migration. In: Bignon J, Peto J, sition, dissolution and migration. In: Bignon J, Peto J, Saracci R, eds. Non-occupational exposure to mineral
fibres. Lyon: IARC, 1989:33-45. (IARC Sci Publ No fibres.

12 Pooley FD. An examination of the fibrous mineral content of asbestos lung tissue from the Canadian chrysotile mining industry. Environ Res 1976;12:281-98.

13 Rowlands N, Gibbs GW, McDonald AD. Asbestos fibres in the lungs of chrysotile miners and millers-a preliminary report. Ann Occup Hyg 1982;26:411-5.

14 Sébastien P, Bégin R, Case BW, McDonald JC Inhalation of chrysotile dust. In: Wagner JC, ed. Biological effects of chrysotile (Accomplishments in Oncology. Vol 1. No 2). Philadelphia: Lippincott, 1986: 19-29.

$15 \mathrm{Du}$ Toit RSJ. An estimate of the rate at which crocidolite asbestos fibres are cleared from the lung. Ann Occup Hyg 1991;35:433-8.

16 Berry G, Rogers AJ, Pooley FD. Mesotheliomas-asbestos exposure and lung burden. In: Bignon J, Peto J, Saracci $\mathrm{R}$, eds. Non-occupational exposure to mineral fibres. Lyon IARC, 1989:486-96. (IARC Sci Publ No 90)

17 Albin M, Jakobsson K, Attewell R, Johansson L, Welinder $\mathrm{H}$. Mortality and cancer morbidity in cohorts of asbestos cement workers and referents. $\mathrm{Br} \mathcal{F}$ Ind $\mathrm{Med}$ 1990;47:602-10

18 Johansson L, Albin M, Jakobsson $K$, Welinder $H$, Ranstam J, Attewell R. Ferruginous bodies and pulmonary fibrosis in dead low to moderately exposed asbestos cement workers: histological examination. $\mathrm{Br} \mathcal{F}$ Ind Med 1987;44:550-8.

19 Albin M, Johansson L, Pooley FD, Jakobsson K, Attewell R, Mitha R. Mineral fibres, fibrosis, and asbestos bodies in lung tissue from deceased asbestos cement workers. in lung tissue from deceased

20 Addison J, Davies LST. Analysis of amphibole asbestos in chrysotile and other minerals. Ann Occup Hyg 1990;34 159-75.

21 Pooley FD, Clark NJ. Quantitative assessment of inorganic fibrous particulates in dust samples with an analytical transmission electron microscope. Ann Occup Hyg 1979;22:253-71.

22 Fisher RA. Statistical methods for research workers. 10th ed. Edinburgh: Oliver and Boyd, 1948.

23 Sébastien P, Fondimare A, Bignon J, Monchaux G, Desbordes J, Bonnaud G. Topographical distribution of asbestos fibres in human lung in relation to occupational and non-occupational exposure. In: Walton WH ed. Inhaled particles IV. Edinburgh 1975. Part 2. Oxford: ed. Inhaled particles IV. Edinbur

24 Churg A, Wood P. Observations on the distribution of asbestos fibers in human lungs. Environ Res 1983;31: 374-80.

25 Morgan A, Holmes A. Distribution and characteristics of amphibole asbestos fibres, measured with the light microscope, in the left lung of an insulation worker. $\mathrm{BrF}$ Ind Med 1983;40:45-50.

26 Pooley FD, Mitha R. Fiber types, concentrations and characteristics found in lung tissues of chrysotileexposed cases and controls. In: Wagner JC, ed. Biological effects of chrysotile. (Accomplishments in Oncology. Vol 1. No 2). Philadelphia: Lippincott, 1986: $1-11$.

27 Timbrell V. Pulmonary deposition and retention of South African amphibole fibres; identification of asbestosisrelated measure of fibre concentration. In: Proceedings of the VIth International Pneumoconiosis Conference. Geneva: International Labour Office, 1984;2:997-1008.

28 Sébastien P, McDonald JC, McDonald AD, Case B, Harley R. Respiratory cancer in chrysotile textile and mining industries: exposure inferences from lung analysis. Br F Ind Med 1989;46:180-7.

29 Churg A, Wiggs B. Mineral particles, mineral fibres, and lung cancer. Environ Res 1985;37:364-72.

30 McFadden D, Wright J, Wiggs B, Churg A. Cigarette smoke increases the penetration of asbestos fibres into airway walls. Am $\mathcal{F}$ Pathol 1986;123:95-9.

31 Kilburn KH, Lilis R, Anderson HA, Miller A, Warshaw $\mathrm{RH}$. Interaction of asbestos, age and cigarette smoking in producing radiographic evidence of diffuse pulmonary fibrosis. Am $¥ \mathrm{Med} 1986 ; 80: 377-81$.

32 Saracci $R$. Asbestos and lung cancer: an analysis of the epidemiological evidence on the asbestos-smoking interaction. Int $\mathcal{f}$ Cancer 1977;20:323-31.

33 Wagner JC, Newhouse ML, Corrin B, Rossiter CE, Griffiths DM. Correlation between fibre content of the lung and disease in east London asbestos factory workers. $\mathrm{Br} \mathcal{F}$ Ind Med 1988;45:305-8. 